\section{Respon Guru dan Siswa SMA Terhadap Penggunaan Quipper School Dalam Blended Learning pada Pembelajaran Biologi}

\author{
Abd. Muis \\ Arsad Bahri
}

Abstrak. Efektivitas suatu inovasi pembelajaran tidak bisa mengabaikan aspek
penting karakteristik siswa. Tujuan penelitian ini adalah untuk
mendeskripsikan respon guru dan siswa SMA terhadap pembelajaran blended
learning (BL) menggunakan quipper school. Responden penelitian ini adalah 21
orang guru dan 81 orang siswa kelas XI MIA SMA Negeri 1 Pangkajene Sidrap,
Kabupaten Sidrap. Gambaran tentang respons guru dan siswa terhadap
penggunaan quipper school dalam blended learning pada pembelajaran
biologi, digunakan angket respon guru dan siswa. Hasil penelitian
menunjukkan bahwa guru dan siswa memberikan respon yang positif terhadap
penggunaan quipper shool dalam BL. Hal ini membuktikan bahwa penggunaan
quipper school dalam BL efektif digunakan dalam pembelajaran di sekolah
menengah atas dengan mempertimbangkan berbagai aspek seperti
karakteristik siswa, ketersediaan sarana dan prasarana pendukung, dan
kemampuan guru menggunakan teknologi.
Kata Kunci: blended learning, pembelajaran online, quipper school, respon guru, respon siswa.

\section{Pendahuluan}

Peran teknologi sangat penting dalam memungkinkan perkembangan inovasi baru seperti video; web; virtual atau media sosial terkini akan mengantarkan terobosan besar dalam penyediaan pendidikan. Hal ini disarankan sebab inovasi baru dalam dunia pendidikan akan memberikan perubahan terhadap proses pembelajaran konvensional. Paling tidak, diharapkan pembelajaran konvensional yang ada harus mengadopsi metode yang baru (Fleck, 2012). Di beberapa sekolah, guru telah meningkatkan penggunaan konten dan sumber berbasis internet dalam proses pembelajaran mereka. Evolusi ini sering didorong oleh sejumlah kecil guru yang tekun mencari cara baru untuk memberi konten yang memperkaya dan memperluas pembelajaran di luar jam pelajaran dan hari sekolah (Watson, 2008). Sehingga penting bagi guru memiliki pengetahuan untuk mengintegrasikan teknologi dalam kegiatan pembelajarannya.

Salah satu pengitegrasian teknologi ke dalam kurikulum pembelajaran saat ini adalah dengan penerapan pembelajaran online atau sering kita kenal dengan istilah electronic learning (e-learning). E-learning pada hakekatnya adalah belajar atau pembelajaran melalui pemanfaatan teknologi komputer atau internet yang memberikan efektivitas dan efisiensi dalam pembelajaran (HodHod et al., 2010). Kelebihan yang dimiliki e-learning antara lain seperti, kemudahan dalam melaksanakan proses pembelajaran dimana saja dan kapan saja, meningkatkan

\section{Biology Teaching and Learning}

p-ISSN 2621 - 5527

e-ISSN 2621 - 5535

Abstract. The effectiveness of a learning innovation cannot ignore the important aspects of student characteristics. The purpose of this study was to describe the response of high school teachers and students to blended learning (BL) using quipper school. Respondents of this study were 21 teachers and 81 students of class XI MIA 1 SMA Pangkajene Sidrap, Sidrap Regency. The response of teachers and students to the use of quipper school in blended learning in biology learning, measured by the teacher and student response questionnaire. The results showed that teachers and students gave a positive response to the use of quipper shool in BL. This proves that the use of quipper school in BL is effectively used in high school learning by considering various aspects such as student

characteristics, availability of supporting facilities and infrastructure, and the ability of teachers to use technology. Keywords: blended learning, online learning, quipper school, teachers' response, students' response.

Abd. Muis

Universitas Negeri Makassar Indonesia

Arsad Bahri

Universitas Negeri Makassar Indonesia 
belajar siswa, kemudahan dalam mengumpulkan informasi dengan mengakses internet, dan meningkatkat evektifitas dan efisiensi pembelajaran.

Kegiatan pembelajaran yang terjadi di beberapa sekolah menengah menunjukkan aktifitas siswa yang cenderung mendengarkan penyampaian oleh guru. Sehingga pembelajaran menjadi kurang interaktif dan kolaboatif. Hal ini yang menjadi keluhan guru saat dilakukan observasi terhadap pengelolan kelas dalam proses pemebelajaran. Namun ini juga dapat disebabkan oleh guru yang kuran inovatif dalam memberikan pemebelajaran di dalam kelas. Guru seharusnya lebih tahu apa yang dibutuhkan oles siswa dan lebih paham mengenai penggunaan metode dan media yang sesuai untuk menarik minat dan motivasi belajar siswa sehingga merekalebih aktif dan pembelajaran menjadi lebih efektif.

Rohmawati (2015), keefektifan dalam pembelajaran adalah ukuran keberhasilan dari suatu proses interaksi antar siswa maupun antara siswa dengan guru dalam situasi edukatif untuk mencapai tujuan pembelajaran. Menurut Susilo (2013) pembelajaran akan menjadi efektif tergantung dari kemampuan guru dalam mengelola pembelajaran. Seorang guru yang tidak menguasai materi yang akan diajarkan tidak akan bisa mengajar dengan baik. Demikian pula bila seorang guru tidak menguasai berbagai cara penyampaian materi, maka akan dapat menimbulkan kesulitan peserta didik dalam memahami materi. Selain itu, seorang guru yang baik harus memiliki kemampuan dalam menerapkan prinsip-prinsip psikologis, kemampuan dalam menyelenggarakan proses belajar mengajar serta kemampuan dalam memyesuaikan diri dengan situasi yang baru.

Situasi baru yang ditawarkan di era modern ini adalan dengan mengintergrasikan Information and Communication Technology (ICT) yang sedang berkembang saat ini. Kemajuan ICT sekarang ini memiliki potensi sangat besar dalam mengembangkan lingkungan belajar konstruktivis untuk memfasilitasi pembelajaran. Penerapan pembelajaran berbasis ICT seperti disebutkan sebelumnya yaitu electronic learning memiliki yang banyak keunggulan dilihat dari kekayaan sumber belajar (learning resources) dan aktvitas belajar (learning task). Kudwadi (2006) ICT dimanfaatkan dalam dunia pendidikan dengan mengunakan teknologi e-learning. Dalam konteks jaringan, $e$-learning didefinisikan sebagai upaya menghubungkan pebelajar (peserta didik) dengan sumber belajarnya (database, pakar/guru/dosen, perpustakaan) yang secara fisik terpisah dan berjauhan, dimana interaktivitas dalam hubungan tersebut dilakukan secara langsung maupun tidak langsung.

Pemanfaatan teknologi ICT dalam pembelajaran tidak serta merta membuktikan keunggulan yang dijanjikannya. Secanggih apapun teknologi, teknologi bukanlah obat yang paling ampuh untuk menyembuhkan semua penyakit, ataupun tongkat ajaib yang bisa dengan mudah menyelesaikan masalah, khususnya maslah dalam proses pembelajaran. Teknologi tidak bisa memberikan efektivitasnya dalam pembelajaran sebab efektivitas teknologi sangat tergantung pada bagaimana teknologi tersebut diintegrasikan atau dimanfaatkan dalam pembelajaran (Roblyer, 2006).

Pemanfaatan Teknologi ICT dalam proses pembelajaran khususnya pemanfaatan teknologi internet, tentunya membawa pengaruh besar terhadap proses pembelajaran, Namun, siswa belum terbiasa dengan sistem pembelajaran tersebut, sehingga penerapan pembelajaran online kurang efektif. Siswa masih terbiasa dengan gaya belajar konvensional yang selama ini lakukan oleh guru. Hal ini sejalan dengan Kirna (2013) menemukan bahwa penyebab kurang efektifnya pembelajaran online dikontribusi oleh budaya belajar siswa. Sebagian besar siswa belum terbiasa belajar aktif dan produktif. Gaya belajar siswa yang sudah terbentuk dari pembelajaran tradisional memerlukan waktu adaptasi yang cukup untuk menggeser gaya belajarnya yang cenderung pasif dengan gaya yang baru seperti ditawarkan oleh pembelajaran online. Artinya, pengintegrasian teknologi dalam pembelajaran tidak boleh mengabaikan karakteristik siswa. Dabbagh \& Ritland (2005) juga menyatakan bahwa keberhasilan pembelajaran online juga mempersyaratkan siswa yang selfdirected, selfregulated, self diciplined, dan confortable with written communication memiliki karakter berbagi informasi, dan memiliki keterampilan teknis teknologi. Morin, dkk. (2015) menyatakan bahwa "Perceptions are, therefore, important considerations when integrating technology into learning, especially virtual learning."

Pemanfaatan ICT oleh praktisi pendidikan juga tanpa basis pedagogi memadai sehingga 
efektivitasnya sangat bervariasi. Beberapa temuan penelitian melaporkan bahwa pemanfaatan ICT memberikan hasil yang tidak konsisten (Passerini, 2007). Hasil yang tidak konsisten ini sebagian disebabkan oleh rendahnya kuatlitas sumber belajar berbasis ICT yang digunakan dan belum tepatnya strategi pengintegrasianya dalam pembelajaran. Leacock dan Nesbit (2007) menemukan bahwa sebagian besar kualitas lingkungan belajar online dan standar kualitas konten yang masih rendah dan belumdirancang sesuai dengan karakteristik subjek dan pedagogi. Pemanfaatan ICT masih mengalami banyak kendala, utamanya ketersediaan sumber belajar digital yang berkualitas dan literasi teknologi (internet) dari guru dan siswa (Hew \& Brush, 2007). Barger dan Byrd (2011) mengemukakan bahwa hal yang paling penting menentukan keberhasilan pembelajaran online adalah ketersediaan lingkungan belajar online (konten online) yang tepat.

Penyebaran internet telah meningkatkan kualitas sumber daya telah mendorong terciptanya program yang memadukan pembelajaran online dan pengajaran tatap muka. Blended learning (BL) adalah kombinasi strategi penyampaian pembelajaran yang mengambil keunggulan pembelajaran online dan tatap muka. Temuan sejumlah penelitian (Vaughan, 2007; Kim \& Bateman, 2010; Shroff, \& Deneen, 2011; Rosenthal \& Weitz, 2012; Kirna, 2013) mengemukakan efektivitas dari penerapan BL.

Penelitian yang dilakukan beberapa tahun terakhir, menunjukkan efektifitas BL. Dari meta analisis yang dilakukannya, Means, dkk. menemukan bahwa BL lebih efektif meningkatkan hasil belajar daripada pembelajaran online dan tatap muka yang dilakukan secara terpisah. Chou \& Chou (2011) pembelajaran yang inovatif dapat diciptakan melalui tiga gambaran pembelajaran yaitu, pembelajaran tatap muka (face to face), pembelajaran online (e-learning), dan pembelajaran campuran (blended learning). Ajide \& Tik (2009) melakukan penelitian untuk mengetahui efektifitas BL yang dilaksanakan dengan menggunakan learning managemant system (LMS). Hasil penelitiannya menunjukan bahwa peserta didik lebih aktif dalam proses pembelajaran. Peseta didik menunjukkan sikap positif terhadap blended learning, mereka memiliki persepsi konsep yang baik. Hal ini berarti bahwa BL sangat efektif dalam mencapai tujuan pembelajaran.

LMS dapat digunakan siswa dalam belajar biologi melalui penerapan BL yang mengakomodasi pembelajaran di kelas dan di luar kelas. Untuk mengakomodasi pembelajaran online dilakukan dengan bantuan quipper school. Quipper school sebagai media sarana membantu memudahkan guru dan siswa, media ini termasuk di dalam e-learning. E-learning mampu meningkatkan pengalaman belajar sebab siswa dapat belajar dimanapun dan dalam kondisi apapun selama dirinya terhubung dengan internet tanpa harus mengikuti pembelajaran tatap muka (face to face learning) (Castle \& McGuire, 2010). Penggunaan media quipper school bertujuan untuk menciptakan interaksi belajar siswa secara aktif dalam mengikuti pembelajaran di kelas maupun diluar kelas yang nantinya akan memacu motivasi dan konsentrasi siswa dalam menerima pembelajaran. Perpaduan pembelajaran konvensional (tatap muka) dan pemberian kuis berbasis ICT dengan prinsip e-learning diharapkan akan memberikan dampak yang positif terhadap pengalaman belajar siswa. Siswa bukan saja aktif dalam mengikuti pembelajaran namun siswa juga akan terpacu untuk mendapatkan skor tertinggi di kelasnya.

\section{Fokus Penelitian}

Berdasarkan pernyataan diatas, tujuan penelitian ini adalah untuk mengeksplorasi respon guru dan siswa SMA terhadap penggunaan quipper school dalam BL. Respon guru dan siswa ini sangat berguna dalam merancang konten online yang efektif dan inovatif untuk mendukung Quipper School dalam pengelolaan BL pada pembelajaran biologi SMA.

\section{Metode Penelitian}

\section{Latar Belakang Umum Penelitian}

Penelitian ini termasuk penelitian desktiptif kualitatif untuk mendeskripsikan sekaligus menginterpretasi dan mengelaborasi temuan. Penelitian dilaksanakan pada tahun 2017. 


\section{Sampel Penelitian}

Responden penelitian adalah guru dan siswa SMA kelas XI MIA di SMA 1 Pangakajene Sidrap, Kabupaten Sidrap, yang terdiri atas 81 orang siswa dan 21 orang guru Pemilihan sekolah sebagai subjek penelitian didasarkan atas pertimbangan bahwa guru-guru dan siswa di sekolah tersebut memiliki literasi yang baik dalam bidang ICT/internet terutama dalam hal penggunaan quipper school dalam pengelolaan BL.

\section{Instrumen dan Prosedur}

Dua jenis angket dibuat pada penelitian ini, yaitu angket respons/persepsi guru dan angket respons/persepsi siswa tentang pembelajaran yang dilaksanakan secara BL dengan menggunakan quipper school. Angket respon guru memuat aspek penilaian yang digunakan untuk mengukur efektifitas pembelajaran dangan quipper school. Angket respon siswa disusun mengacu pada teori motivasi (Keller, 2000) yang terdiri atas 4 aspek, yaitu atensi, relevansi, kepercayaan diri, dan kepuasan.

Angket disebarkan secara manual tanpa identitas responden. Jenis angket yang digunakan adalah skala likert yang digunakan untuk mengukur persepsi, sikap atau pendapat seseorang atau kelompok mengenai sebuah peristiwa atau fenomena sosial, berdasarkan definisi operasional yang telah ditetapkan oleh peneliti. Pengisian angket dikoordinasikan oleh salah satu guru dari sekolah yang dijadikan subjek penelitian.

\section{Analisis Data}

Data respon guru dan siswa dianalisis menggunakan tekhnik analisis statistic deskriptif. Hasil elaborasi respon guru dan siswa dan harapan siswa terhadap penggunaan quipper school dalam pengelolaan BL dijadikan pertimbangan untuk merancang konten online dan strategi pengelolaan pembelajaran BL di SMA menggunakan quipper school.

\section{Hasil Penelitian}

Sebanyak 81 orang siswa dan 21 orang guru yang masing - masing mengisi angket respon terhadap pembelajaran yang dilaksanakan secara BL dengan menggunakan quipper school. Analisis datarespon siwa terhadap penggunaan quipper school dalam pengelolaan BL dapat dilihat pada tabel berikut.

Tabel 1. Respon Siswa Terhadap Quipper School

\begin{tabular}{|c|c|c|c|c|}
\hline \multirow{2}{*}{ Respon } & \multicolumn{4}{|c|}{ Persentase (\%) } \\
\cline { 2 - 5 } & Attention & Relevance & Confidence & Satisfaction \\
\hline Positif & 71 & 78 & 73 & 74 \\
\hline Netral & 20 & 13 & 21 & 17 \\
\hline Negatif & 9 & 9 & 6 & 9 \\
\hline
\end{tabular}

Tabel 1 menunjukkan bahwa secara umum siswa merespon positif penggunaan Quipper School dalam BL pada pembelajaran biologi di SMA 1 Pangkajene Sidrap, Kabupaten Sidrap. Hal ini terlihat pada keempat indikator pada respon siswa, lebih dari 70\% siswa yang merespon positif.

Tabel 2. Respon Guru Terhadap Quipper School

\begin{tabular}{|c|c|}
\hline Respon & Persentase (\%) \\
\hline Positif & 63,1 \\
\hline Netral & 16,0 \\
\hline Negatif & 20,89 \\
\hline
\end{tabular}


Tabel 2 menunjukkan bahwa secara umum guru merepon positif penggunaan Quipper School dalam BL pada pembelajaran biologi di SMA 1 Pangakajene Sidrap, Kabupaten Sidrap. Hal ini terlihat pada hasil angket yang menunjukkan bahwa 63,1\% guru memberikan respon yang positif.

\section{Pembahasan}

Quipper school merupakan salah satu media pembelajaran yang berbasis learning management system (LMS) yang biasa digunakan dalam menerapkan BL. Sejzi (2013) menyatakan bahwa media quipper school sudah memenuhi syarat dalam menjalankan fungsi sebagai media LMS. Berdasarkan pusat pengembangan quipper school (2016), quipper School adalah sebuah platform online gratis untuk guru dan siswa. Menurut Kulshrestha (2013) ada beberapa fitur umum yang di syaratkan sehingga LMS bisa menjalankan fungsinya dengan baik, yaitu manajemen konten (content management), penilaian dan pengujian (assessment and testing), perencanaan kurikulum (curriculum planning), laporan berkala (reports generation), komunikasi dan kolaborasi (communication and colaboration), LMS menyediakan obrolan, forum, atau pesan sehingga pengguna LMS dapat saling berkomunikasi, pengumuman kelas dan kuliah (classroom dan college announcements).

Hasil penelitian yang telah dilakukan menunjukkan atensi/ketertarikan siswa terhadap penggunaan quipper school dalam pengelolaan blended learning menunjukkan secara umum tanggapan yang positif. Ini berarti bahwa e-learning quipper school menumbuhkan kesenangan belajar siswa, menghilangkan kesalahan pemahan konsep, meningkatkan retensi siswa, dan membuat siswa lebih mudah memahami pelajaran. Walaupun sebagian responden belum pernah terlibat dalam pembelajaran BL atau mengikuti BL hanya sebatas tugas untuk mencari informasi melalui internet, tetapi sebagian besar responden senang terhadap aktivitas tersebut. Atensi reponden yang tinggi terhadap penerapan BL terlihat dari respon positif mereka agar sebagian besar pembelajaran dilaksanakan dengan memanfaatkan ICT dan mereka ingin mengikuti pembelajaran BL terlepas dari strategi itu cocok atau tidak cocok dengan cara/kebiasaan belajarnya. Sejalan dengan Kirna et. al.(2015) menemukan bahwa tingkat atensi siswa terhadap pembelajaran yang disampaikan secara BL termasuk kategori tinggi. BL terlah dipandang positif oleh siswa SMA, sehingga perlu dipertahankan melalui perancangan dan perencanaan BL yang baik.

Respon siswa dilihat dari aspek ketertarikan/relevance juga menunjukkan tanggapan yang positif. Siswa menganggap bahwa penerapan quipper school menarik dan tidak membosankan, serta memberikan waktu yang efisien bagi siswa dalam memahami konsep dengan baik. Respon positif siswa juga terlihat pada aspek percaya diri/confidance diri. siswa lebih termotivasi untuk belajar, meningkatkan penalaran individu membantu proses berpikir kritis siswa. Kepuasan/Satisfaction siswa menunjukkan respon positif. siswa merasa lebih dihargai dalam mengeluarkan pendapat dan memiliki keberanian untuk mengeluarkan pendapat.

Keseluruhan respons positif siswa terhadap ARCS termasuk kategori tinggi. Siswa SMA kelas XI MIA di SMA 1 Pangakajene Sidrap, Kabupaten Sidrap memiliki motivasi awal yang tinggi terhadap pembelajaran dengan quipper school yang disampaikan melalui BL. Hasil penelitian yang dilakukan oleh Ajide \& Tik (2009) menunjukan bahwa peserta didik menunjukkan sikap positif terhadap BL, mereka memiliki persepsi konsep yang baik.

Respon positif siswa terhadap BL merupakan titik awal terhadap penerapan quipper school dalam pengelolaan BL. Respons positif sangat berkaitan dengan partisipasi aktif siswa dalam pembelajaran (Barger \& Byrd, 2011). Motivasi awal yang baik perlu dijaga dengan merancang pembelajaran BL yang berbasis pada model motivasi. Keller (2000) menyatakan bahwa mempertahankan atensi adalah bagian akhir yang harus dilakukan pada aspek atensi dari model motivasi Attention, Relevance, Confidence, Satisfaction (ARCS) yang digagasnya. Relevansi adalah aspek kedua dari model motivasi ARCS. Walaupun siswa memiliki rasa ingin tahu yang tinggi dan atensi yang sangat tinggi, tetapi motivasinya akan hilang apabila tidak memberikan nilai manfaat kepada dirinya. Sesuatu yang sesuai/relevan dengan kebutuhan atau tujuan akan meningkatkan motivasi 
Hasil meta analisis yang dilakukan oleh Means, dkk. (2014) telah menegaskan bahwa keunggulan BL dari pembelajaran online dan tatap muka salah satunya disebabkan oleh lamanya waktu siswa berinteraksi aktif dalam lingkungan belajar online (time engagement). Time engagement ini dikontribusi oleh fleksibilitas pembelajaran online dari segi waktu dan tempat dan juga faktor motivasi. Wright (2017) melakukan penelitian yang menunjukkan bahwa siswa memilih pembelajaran secara online karena kecepatan dan kenyamanan belajar dan fleksibilitas waktu dan tempat. Penerapan pelajaran online yang terampil dapat meningkatkan kualitas proses pembelajaran namun tidak boleh mengurangi nilai instruksi tatap muka dengan guru.

Hasil penelitian ini juga menunjukkan siswa menunjukkan respon negatif. Hal ini disebabkan oleh gaya belajar siswa, yang belum terbiasa menerima pembelajaran melalui BL. Meskipun demikian, siswa memiliki ketertarikan yang tinggi terhadap BL. Siswa tidak memiliki kendala pada saat menggunakan internet dalam penerapan quipper school yang disampaikan melalui BL sebab siswa memiliki keterampilan terhadap penggunaan teknologi. Sehingga respon positif dari siswa dan keterampilang penggunaan teknologi yang dimiliki oleh siswa mendukung penerapan BL yang diterapkan kepada siswa kelas XI MIA di SMA 1 Pangakajene Sidrap. Hasil-hasil penelitian Alayar et. al. (2012) memperlihatkan bahwa respons positif dan skill adalah faktor kunci dalammemulai pembelajaran berbasis ICT. Respon dan keterampilan menggunakan internet ini belum menjamin pembelajaran berbasis ICT, seperti BL akan efektif. Beberapa hasil penelitian menemukan bahwa keberhasilan pembelajaran online mempersyaratkan siswa agar memiliki kemampuan self-directed learning, motivasi internal, internal locus of control, keterampilan berkolaborasi, dan karakter membagi informasi (Dabbagh \& Ritland, 2005).

Pembelajaran BL melalui penerapan quipper school memberikan kesempatan bagi siswa untuk belajar secara mandiri dengan disediakannya berbagai media dan sumber belajar yang mendukung proses pengumpulan informasi oleh siswa. BL juga menciptakan lingkungan pembelajaran yang interaktif antara guru dengan siswa maupun antara siswa dengan siswa lainnya melalui forum diskusi yang disediakan di dalam quipper school. Means, dkk. (2014) juga menemukan bahwa efektivitas pembelajaran BL salah satunya dikontribusi oleh interaksi siswa dengan siswa. Diskusi online memiliki keunggulan yaitu pembelajar memiliki kebebasan psikologis dalam mengajukan dan menanggapi permasalahan teman (Kirna, 2013). Temuan ini lebih dipertegas oleh Roberts dan Kanagasabai (2013) yang melaporkan bahwa pembelajar secara signifikan lebih menyukai posting problem atau tanggapan ke forum diskusi secara anonim (anonymous posting) disbandingkan dengan tidak anonim (identified posting).

Marsh (2012) menyatakana beberapa kelebihan BL yakni: 1) memberikan pengalaman belajar yang lebih individual, 2) memberikan dukungan belajar yang lebih personal, 3) mendukung dan mendorong pembelajaran mandiri dan kolaboratif, 4) meningkatkan keterlibatan peserta didik dalam belajar, 5) mengakomodasi berbagai gaya belajar, 6) menyediakan tempat untuk berlatih di luar ruang kelas, 7) menyediakan lingkungan belajar mengurangi stress, 8) memberikan studi yang fleksibel, kapan atau di mana saja, untuk memenuhi kebutuhan peserta didik, dan 9) membantu peserta didik mengembangkan keterampilan belajar yang bernilai dan dibutuhkan pada abad dua puluh satu.

Pembelajaran mandiri, merujuk pada pembelajaran yang berasal dari pemikiran dan perilaku yang dihasilkan sendiri oleh siswa yang secara sistematis diarahkan ke sasaran pembelajaran mereka (Slavin, 2009:115). Motivasi intrinsik siswa pada umumnya menurun dari sekolah dasar tahun-tahun pertama hingga sekolah menengah. Karena alasan ini sekolah menerapkan berbagai insentif ekstrinsik (extrinsic incentive), yaitu imbalan untuk pembelajaran yang tidak melekat dalam bahan yang sedang dipelajari (Slavin, 2009:130). Imbalan ekstrinsik dapat berkisar dari pujian, nilai, penghargaan, hingga hadiah atau imbalan lain. Fenomena motivasi intrinsik mencerminkan kecenderungan utama manusia untuk terlibat dalam kegiatan yang menarik perhatian mereka untuk belajar, mengembangkan dan memperluas kapasitas mereka. Motivasi intrinsik yang terkandung setiap kali orang berperilaku untuk kepuasan yang melekat dalam perilaku itu sendiri (Sansone, Harackiewicz, 2000:16).

Penelitian ini juga mengukur respon guru terhadap quipper school dalam pengelolaan blended learning. Guru memberikan respon yang positif terhadap quipper school. Guru merasa 
quipper school cocok untuk diterapkan dalam proses pembelajaran di SMA. Ketersediaan media pembelajaran di dalam quipper school membantu siswa memahami materi plajaran, siswa menjadi lebih aktif dan mampu mengatasi kesulitan belajanya. Disamping itu bbrapa guru juga mmberikan respon negatif trkait penerapan quipper school, hal ini disebabkan oleh beberapa guru masih terbiasa dengan cara mengajar yang konvensional. Guru lebih sering mnggunakan mtode caramah dan kurang mmahami cara untuk mngintegrasikan teknologi dalam proses pmbelajarannya. Namun, guru tetap harus membiasakan diri untuk mmahami pengeintegrasian tknologi dalam pembelajaran. Sejalan dengan pnnlitian yang dilakukan oleh Koehler \& Mishra (2009) bahwa guru prlu mengintgrasikan teknologi utuk pengajaran yang fektif. Kerangka technology, pedagogy, and content knowledge (TPACK) mengharuskan guru memiliki pengetahuan dari interaksi yang kompleks antara tiga komponen pengetahuan akan konten, pengetahuan pedagogi, dan pengetahuan dalam menggunakan teknologi. Interaksi dari komponen pengetahuan ini, baik secara teoritis maupun praktis, menghasilkan jenis pengetahuan fleksibel yang dibutuhkan untuk mengintegrasikan penggunaan teknologi ke dalam pengajaran dengan sukses (Koehler \& Mishra, 2009). Sebagaimana yang tertuang dalam kurikulum 2013 yang menyatakan bahwa salah satu prinsip pembelajaran yang digunakan untuk mencapai standar kompetensi lulusan dan standar isi yaitu pemanfaatan teknologi informasi dan komunikasi untuk meningkatkan efisiensi dan efektivitas pembelajaran.

\section{Kesimpulan}

Siswa kelas XI MIA di SMA 1 Pangakajene Sidrap memiliki respon positif terhadap terhadap quipper school dalam pengelolaan blended learning (BL) baik dilihat dari atensi/ketertarikan ketertarikan/relevance, percaya diri/confidance, kepuasan/satisfaction. Guru juga memberikan respon yang positif trhadap BL. Respon positif dari guru dan siswa perlu direalisasikan untuk menerapkan BL yang dirancang dengan baik.

\section{Referensi}

Ajide, O. E., \& Tik, C. C. (2009). A Study on The Effectiveness of Blended Learning. $2^{\text {nd }}$ International Conference of Teaching and Learning (pp. 1-7). Malaysia: INTI University College.

Allayar, G. M., Fisser, P., Voogt, F. (2012). Developing Technological Pedagogical Content Knowledge jn Pre-Service Science Teachers: Support from Blended Learning. Australasian Journal of Educational Technology, 28 (8), 1298-1316.

Allen's, M. (2007). Designing Successful E-Learning: Forget What You Know About Instructional Design and Do Something Interesting. San Francisco: Pleiffer.

Anglin, G. J., Vaez, H. \& Cunningham, K. L. (2004). Visual Representations and Learning: The Role of Static and Animated Graphics. Dalam David H. Jonassen (Ed.). Handbook of Research on Educational Communications and Technology (hlm. 865-916). Mahwah: Lawrence Erlbaum Associates.

Barger, A., \& Byrd, K. (2011). Motivation and Computer-Based Instructional Design. Journal of CrossDisciplinary Perspectives in Education, 4 (1), 1-9.

Bransford, J. D., Brown, A. L., \& Cocking, R. C. (2000). How People Learn, Brain, Mind, Experience, and School. Washington. D.C.: National Academy Press.

Cahyadi, F.D. (2011). Penerapan Blended Learning Dalam Pembelajaran Biologi Untuk Meningkatkan Kemampuan Berpikir Kritis Siswa Kelas Xi Ipa 4 Putra Sma Rsbi Pondok Pesantren Modern Islam Assalaam Sukoharjo Tahun Pelajaran 2011/2012. Online Jurnal UNNES, 4 (1), 15-22. 
Respon Guru dan Siswa Terhadap Penggunaan Quipper School Dalam Blended

Learning pada Pembelajaran Biologi

(hlm. 162-171)

p-ISSN 2621-5527

e-ISSN 2621-5535

Castle, SR. \& McGuire, CJ. (2010). An analysis of student self assessment of online, blended, and face to face learning environments: implication for sustainable education delivery. Journal of International Education Studies, 3 (3), 30-36.

Chou, A. Y. \& Chou, D. C. (2011). Course Management Systems and Blended Learning: An Innovative Learning Approach. Decision Sciences Journal of Innovative Education, 9 (3), 463-484.

Dabbagh, N., \& Ritland, B. B. (2005). Online Learning: Concepts, Strategies, and Application. Upper Saddle River: Pearson Education, Inc.

Falvo, D. (2008). Animations and Simulations for Teaching and Learning Molecular Chemistry. International Journal of Technology in Teaching and Learning, 4 (1), 68-77.

Fleck. J. (2012). Blended learning and Learning Communities: Opportunities and Challenges", Journal of Management Development, 31 (4), 398 - 411.

Hew, K. F., \& Brush, T. (2007). Integrating technology into K-12 teaching and learning: Current knowledge gaps and recommenddations for future research. Educational Technology Research and Development, 55 (3), 223-252.

Hodhod, R., Ibrahim, M., Khafagy, M., \& Abdel-Wahab, M.S. (2010). Issues of Choosing the Suitable Virtual Learning Environment. Research Journal of Information Technology, 2 (1), 24-29.

Keller, J. M. (2010). What is Motivational Design? (Online), (www.springer. com/../9781441 912497-c1.pdf, diakses 20 Oktober 2017)

Kim, H. K. \& Bateman, B. (2010). Student Participation Patterns in Online Discussion: Incorporating Constructivist Discussion into Online Courses. International Journal on E-Learning, 9 (1), 7998.

Kirna, I M. (2013). Penerapan Strategi Problem Posing yang disampaikan secara Blended Learning pada Perkuliahan Chemical Bonding. Prosiding Seminar Nasional FMIPA III di UNDIKSHA, 30 Nopember 2013.

Kirna, I. M. (2012). Pemahaman Konseptual Pebelajar Kimia Pemula dalam Pembelajaran Berbantuan Multimedia Interaktif. Jurnal Ilmu Pendidikan, 18 (1), 88-97.

Koehler, M. J., \& Mishra, P. (2009). What Is Technology Pedagogy Content Knowledge. Contemporary Issues in Technology and Teacher Education, 9 (1), 60-70.

Kudwadi, B. (2006). Pengembangan Kerangka Model E-Learning dalam Pembelajaran Teknologi dan Kejuruan. Artikel Penelitian Universitas Pendidikan Indonesia. Diakses dari http://file.upi.edu/Direktori/FPTK/IUR.PEND.TEKNIK SIPIL/196707261997031DEDYSURY ADI/Artikel/ArtikelKerangka E-learning.pdf pada tanggal 07 Maret 2017.

Leacock, T. L. \& Nesbit, J. C. (2007). A Framework for Evaluating the Quality of Multimedia Learning Resources. Educational Technology \& Society, 10 (2), 44-59

Marsh, D. (2012). Blended Learning Creating Learning Opportunities for Language Learner. Cambridge, New York, Melbourne, Madrid, Cape Town, Singapore, São Paulo, Delhi, Mexico City: Cambridge University Press.

Marzano, R. J., Pickering, D., \& McTighe, J. (1993). Assessing Students Outcomes, Performance Assessment Using the Dimensions of Learning Model. Alexandria: ASCD. 
p-ISSN 2621-5527

e-ISSN 2621-5535
Respon Guru dan Siswa Terhadap Penggunaan Quipper School Dalam Blended

Learning pada Pembelajaran Biologi

(hlm. 162-171)

Marzano. R. J. (2006). Classroom Assessment \& Grading That Work. Alexandria: ASCD.

Means, B., Toyama, Y., Murphy, R., \& Baki, M. (2014). The Effectiveness of Online and Blended Learning: A Meta-Analysis of the Emperical Literature. Teachers College Record, 115, 1-47.

Merrill, M. D. (2009). First Principles of Instruction. Dalam C. M. Reigeluth, \& A. A. Char-Cheliman (Eds.). Instructional-Design Theories and Models: Building a Common Knowledge Base.), New York: Routledge. 3, 41-56

Morin, D., Thomas, J. D. E., \& Saadé, R. G. (2015). Fostering Problem-Solving in a Virtual Environment. Journal of Information Technology Education: Research, 14, 339- 362.

Passerini, K. (2007). Performance and Behavioral Outcomes in Technology Supported Learning: The Role of Interactive Multimedia. Journal of Educational Multimedia and Hypermedia, 16(2), 183-210.

Pusat Pengembangan Quipper School Indonesia. Diakses dari hhttps://school.quipper.com/id/index.html pada 02 November 2017.

Rahmawati, R., Sudiyanto, Sumaryati, S. (2015). Keefektifan Penerapan E-Learning-Quipper School pada Pembelajaran Akuntansi di SMA Negeri 2 Surakarta. Jurnal Tata Arta, 1(1), 1-12.

Roberts, L. D., \& Kanagasabai, C. J. R. (2013). I'd be so much more Comfortable Posting Anonymously: Identified versus Anonymous Participation in Student Discussion Boards. Australian Journal of Educational Technology, 29 (5), 612-625.

Roblyer, M. D. (2006). Integrating Educational Technology into Teaching (4th Ed.). Upper Saddle River: Pearson Merrill Prentice Hall.

Rohmawati. (2015). Efektivitas Pembelajaran. PAUD PPs Universitas Negeri Jakarta. Jurnal Pendidikan Usia Dini, 9 (1), 1-5.

Rosenthal, D. \& Weitz, R. (2012). Large-Course Redesign via Blended Learning: A PostImplementation Assessment Across Institutions. International Journal on E-Learning, 11 (2), 189-207.

Sanger, M. J., Campbell, E., Felker, J. \& Spencer, C. (2007). Concept Learning versus Problem Solving: Does Particle Mo-tion Have an Effect? Journal of Chemical Education, 84, 875.

Schunk, D. H., Pintrich. P. R., \& Meece, J. L. (2008). Motivation in Education: Theory, Research, and Application. Upper Saddle River: Pearson Education, Inc.

Sejzi, Abdoli, A., \& Baharuddin, A. (2013). Learning management System (LMS) and Learning Content Management System (LCMS) at Virtual University. Malaysia: Department of Educational Science, Mathematic and Multimedia Creative, Faculty of Education, University Teknologi Malaysia.

Shroff, R. \& Deneen, C. (2011). Assessing Online Textual Feedback to Support Student Intrinsic Motivation Using a Collaborative Text-based Dialogue System: A Qualitative Study. International Journal on E-Learning, 10 (1), 87-104.

Smaldino, S. E., Russell, J. D., Heinich, R. \& Molenda, M. (2005). Instructional Technology and Media for Learning (8th Ed.). Upper Saddle River: Pearson Edu-cation, Inc. 
Susilo, F. A. (2013). Peningkatan Efektifitas pada Proses Pembelajaran. Universitas Negeri Surabaya.

Treagust, D. F., Chandrasegaran, A. L., Crowley, J., Yung, B. H. W., Cheong, I. P. A.\& Othman, J. (2010). Evaluating Students' Understanding of Kinetic Particle Theory Concepts Relating to the States of Matter, Changes of State and Diffusion: A Cross-National Study. International Journal of Science and Mathematics Education, 8 (1), 141-164.

Vaughan, N. (2007). Perspectives on Blended Learning in Higher Education. International Journal on E-Learning, 6 (1), 81-94.

Watson, J. (2008). Blending Learning: The Convergence of Online and Face-to-Face Education. North American Council for Online Learning (NACOL). Diakses dari http://files.eric.ed.gov/fulltext/ED509636.pdf pada 4 November 2017

Wijaya, I. K.W.B, Kirna, I M. \& Suardana, I N. (2012). Model Demonstrasi Interaktif dan Hasil Belajar IPA Aspek Kimia Siswa SMP Kelas VII. Jurnal Pendidikan dan Pengajaran, 45 (1), 2301-782.

Wright, B. M. (2017). Blended Learning: Student Perception of Face-to-Face and Online EFL Lessons. Indonesian Journal of Applied Linguistics, 7 (1), 64-71.

\begin{tabular}{|l|l|}
\hline Abd. Muis & Dr., Drs., M.Si., Dosen Jurusan Biologi, Fakultas Matematika dan Ilmu \\
& Pengetahuan Alam, Universitas Negeri Makassar \\
& E-mail: abd.muis@unm.ac.id \\
& Phone Number: 081341019647 \\
\hline Arsad Bahri & Dr., S.Pd., M.Pd., Dosen Jurusan Biologi, Fakultas Matematika dan Ilmu \\
& Pengetahuan Alam, Universitas Negeri Makassar \\
& E-mail: arsad.bahri@unm.ac.id \\
& Phone Number: 081334503202 \\
\hline
\end{tabular}

